\title{
PENGARUH LAYANAN PENDIDIKAN AGAMA DI SEKOLAH TERHADAP RELIGIUSITAS SISWA : Studi Expost Facto di Medan
}

\section{EFFECT OF RELIGIOUS EDUCATION SERVICES AT SCHOOL ON STUDENT RELIGIOSITY: Expost Facto Study in Medan}

\author{
Suhardin \\ Fakultas Agama Islam Univ. Ibnu Chaldun Jakarta \\ Email : suhardin@yahoo.com \\ Hayadin \\ Peneliti Puslitbang Penda Balitbang Kemenag RI \\ Email : hayadin006@gmail.com
}

\begin{abstract}
The purpose of this study is to find out the effect of religious education service level on the student religiosity. The study was conducted at High School and Vocational High School either government and private schools in Medan, North Sumatra using a 1x2 design involving 22 schools selected using purposive random sampling. The data analysis and interpretation show that there is no difference in the value of religiosity of students at school with high and low religious education services. In conclusion, the level of religious education services has no effect on the value of the student religiosity.
\end{abstract}

Keywords: Religious, Student Religiosity, Religious Education Service

\begin{abstract}
Abstrak
Tujuan dari penelitian ini adalah untuk mengetahui pengaruh tingkat pelayanan pendidikan agama dengan religiusitas siswa. Penelitian dilakukan di SMA dan SMK baik negeri maupun sekolah swasta di Medan, Sumatera Utara dengan menggunakan desain $1 \times 2$ yang melibatkan 22 sekolah yang dipilih dengan menggunakan purposive random sampling. Analisis dan interpretasi data menunjukkan bahwa tidak ada perbedaan nilai religiusitas siswa di sekolah-sekolah yang memiliki layanan pendidikan agama tinggi dan dengan pelayanan pendidikan agama rendah. Kesimpulannya, tingkat layanan pendidikan agama tidak memiliki pengaruh terhadap nilai religiusitas siswa.
\end{abstract}

Kata Kunci: Religius, Religiusitas Siswa, Pelayanan Pendidikan Agama. 


\section{PENDAHULUAN}

Undang-undang Sistem Pendidikan Nasional Nomor: 20 Tahun 2003 Bab V pasal 12 ayat (1) a. berbunyi "setiap peserta didik pada setiap satuan pendidikan berhak mendapatkan pendidikan agama sesuai dengan agama yang dianutnya dan diajarkan oleh pendidik yang seagama." Pendidikan Agama bagi peserta didik merupakan pelayanan asasi, yang secara konstitusional diatur oleh undang-undang sistem pendidikan nasional, seperti yang dikutip di atas. ${ }^{1}$

Lebih teknis diatur lagi dalam Peraturan Pemerintah Nomor: 55 Tahun 2007 tentang Pendidikan Agama dan Keagamaan. Pada pasal 1 ayat 1 dijelaskan bahwa "Pendidikan Agama adalah pendidikan yang memberikan pengetahuan dan membentuk sikap, kepribadian dan keterampilan peserta didik dalam mengamalkan ajaran agamanya, yang dilaksanakan sekurang-kurangnya melalui mata pelajaran pada semua jalur, jenjang, dan jenis pendidikan." ${ }^{2}$

Dalam (Peraturan Pemerintah Nomor: 55 Tahun 2007) Pendidikan agama secara substansial membuat siswa memiliki pengetahuan agama, memiliki sikap keberagamaan, berkepribadian sesuai dengan tuntunan agama dan memiliki kemampuan beribadah sesuai dengan tuntunan agama yang dianutnya. Empat hal di atas agak memiliki kemiripan dengan religiusitas, terutama terkait dengan sikap dan kepribadian. (Menurut Ancok)

${ }^{1}$ Undang-Undang Republin Indonesia Nomor 20 Tahun 2003 Pasal 12 ayat (1).

2Peraturan Pemerintah Nomor: 55 Tahun 2007 tentang Pendidikan Agama dan Keagamaan pasal 1 ayat 1 .
Religiusitas secara substansial menjalankan nilai-nilai keagamaan yang diyakini dalam kehidupan sehari-hari. Siswa yang memiliki religiusitas berusaha menghayati dengan sepenuh hati agama yang diyakininya, mengamalkan dengan seoptimal mungkin agama tersebut dalam kehidupannya. Sehingga agama yang diyakini dapat diwujudkan secara real of life, sehingga menjadi kebiasaan personal, komunal, dan cultural. $^{3}$

Penyelenggaraan Pendidikan Agama adalah kewajiban pemerintah yang diemban oleh Kementerian Agama RI. Keberhasilan dan permasalahannya perlu dilakukan kajian yang mendalam. Untuk itu Puslitbang Penda, telah melakukan tugas dan peran tersebut dengan sangat baik. Beberapa product yang telah dihasilkan diantaranya adalah indek layanan Pendidikan Agama 33 (tiga puluh tiga) Propinsi di Indonesia. Satu propinsi dari hasil risearch tersebut kami coba melakukan elaborasi dengan melihat pengaruh layananan Pendidikan Agama di sekolah terhadap Religiusitas siswa.

Rumusan utama dalam penelitian ini adalah apakah terdapat pengaruh layanan pendidikan agama di sekolah terhadap religiusitas siswa? Dari rumusan penelitian tersebut peneliti ingin mengetahui pengaruh layanan pendidikan agama di sekolah terhadap religiusitas siswa.

\section{Kajian Literatur}

Sekolah bagian dari unit layanan pendidikan, yang melakukan proses transformasi, diawali dengan input, proses

${ }^{3}$ Djamaluddin Ancok, Psikologi Islam (Yogyakarta: Pustaka Pelajar, 2011), h. 102 
dan output, dalam sebuah lingkungan sosial. Komponen yang berada dalam lingkungan pendidikan tersebut diantaranya, pengelola sekolah, pimpinan sekolah, pendidik, masyarakat penerima layanan pendidikan dan siswa sebagai penerima layanan pendidikan secara langsung.

Lebih lanjut beberapa pakar menyebutkan bahwa sekolah menurut Uhar tempat proses pembelajaran terjadi. ${ }^{4}$ Pembelajaran di sekolah menurut Wayne memperluas kapasitas dan memunculkan pola pemikiran baru. ${ }^{5}$ Sekolah sebagai penyedia layanan pendidikan agama, menurut Suherman bertugas mengemas dan menyajikan materi pembelajaran agama kepada peserta didik. ${ }^{6}$

Bahan ajar pendidikan agama yang tertuang dalam standar isi Peraturan Pemerintah Nomor: 19 Tahun 2005 wajib diberikan sekolah terhadap peserta didik. Meliputi pertama pengetahuan agama berkaitan dengan keyakinan (theology), sistem peribadatan (ritual), sistem etika dan moral keagamaan (ethic and moralize) dan aturan-aturan dalam kegiatan interaksi dan transaksional (transaksional system).? Kedua, sikap (attitude), Menurut Robbins pernyataan evaluatif terhadap objek, orang atau peristiwa. ${ }^{8}$ Sikap peserta didik yang dibingkai oleh pemahamannya terhadap doktrin kegamaan yang dianutnya masing-

${ }^{4}$ Uhar Suharsaputra. 2010. Administrasi Pendidikan. Bandung, Refika, h. 61.

${ }^{5}$ Wayne. 2014. Administrasi Pendidikan Teori, Riset, dan Praktik. Yogyakarta, Pustaka Pelajar, h. 48.

${ }^{6}$ Suherman, Penelitian Pendidikan (Bandung: UPI, 2011), h.76.

${ }^{7}$ Peraturan Pemerintah Nomor: 19 Tahun 2005.

${ }^{8}$ Stepen Robbin. 2007. Perilaku Organisasi Jakarta; Salemba, h. 203. masing. Ketiga, kepribadian (personality), menurut Jason A.Colquitt ada lima dimensi kepribadian, terlihat dari wujud nyata doktrin kegamaan dalam kehidupan yang di visualisasikan oleh siswa, sebagai effect (pengaruh) dari pendidikan agama. ${ }^{9}$ Dan keempat, keterampilan, menurut Anshari kecakapan seseorang dalam menggunakan akal, pikiran, ide dan kreatifitas, dalam mengerjakan sesuatu yang berkaitan dengan masalah kegamaan. ${ }^{10}$ Pengetahuan, sikap kepribadian dan keterampilan merupakan merupakan satu kesatuan (integreted) dalam kompetensi pendidikan agama pada diri siswa.

Peraturan Pemerintah Nomor 55 Tahun 2007 tentang Pendidikan Agama dan Keagamaan menjelaskan bahwa Pendidikan Agama berfungsi membentuk manusia Indonesia yang beriman dan bertakwa kepada Tuhan Yang Maha Esa serta berkhlak mulia, dan mampu menjaga kedamaian dan kerukunan hubungan intern dan antar umat beragama. ${ }^{11}$ Pada pasal 2 di jelaskan tentang tujuan pendidikan agama. "Pendidikan Agama bertujuan untuk berkembangnya kemampuan peserta didik dalam memahami, menghayati, dan mengamalkan nilai-nilai agama yang menyerasikan penguasaannya dalam ilmu pengetahuan, teknologi dan seni." 12

${ }^{9}$ Jason A.Colquitt, Jeffery A.Lepine, Michael J. Wesson. 2011. Organizational Behavior, Improving Performance and Commitment in the Workplace (Second Edition), New York; McGraw-Hill, h. 296.

${ }^{10}$ Endang Saifuddin Anshari. 1986. Wawasan Islam Pokok-Pokok Pikiran Tentang Islam dan Ummatnya. Jakarta; Rajawali, h.150.

${ }^{11}$ Peraturan Pemerintah Nomor 55 Tahun 2007. ${ }^{12}$ Ibid., 
Dalam konteks otonomi sekolah, setiap sekolah berhak menawarkan pelajaran agama sesuai dengan ciri khasnya. Sekolah Katolik berhak menawarkan pelajaran agama Katolik. Sekolah Kristen menawarkan pelajaran agama Kristen, sekolah Islam menawarkan pelajaran agama Islam. ${ }^{13}$ Akan tetapi sekolah tidak berhak mewajibkan siswa-siswanya dari agama lain mengikuti pelajaran agama sesuai dengan ciri khas keagamaan sekolah yang bersangkutan.

Layanan Pendidikan Agama oleh sekolah di tuangkan dalam sistem administrasi dan manajemen sekolah, seperti yang digambarkan oleh Wayne (2014) dengan menempuh alur fungsi dan garapan untuk mencapai tujuan pendidikan secara produktif (TTP). Fungsi menajerial meliputi perencanaan, pelaksanaan dan pengawasan. Sedangkan garapan manajerial, (1) Sumber Daya manusia (SDM); pimpinan, pendidik dan tenaga kependidikan; (2) Sumber Belajar (SB), buku refrensi, buku paket, bahan ajar, lembar kegiatan siswa, acces internet; (3) Sumber Fasilitas dan Dana (SFD), ruangan kelas, ruang praktek, ruang ibadah, halaman bermain, perpustakaan, dan alokasi anggaran pembiayaan. ${ }^{14}$

Layanan dalam bentuk lain diambil dalam 8 (delapan) standar pelayanan pendidikan; Peraturan Pemerintah Nomor: 19 Tahun 2005 yang berisi (1) Standar Isi; (2) Standar Pengelolaan; (3) Standar pendidik dan tenaga kependidikan; (4) Standar Sarana dan Prasarana; (5) Standar Proses; (6)

\footnotetext{
${ }^{13} \mathrm{Abdul}$ Mukhti, ceramah tentang pengembangan penelitian Pendidikan Agama, tanggal 28 September 2016.

${ }^{14}$ Wayne, op.cit., h. 108
}

Standar Kelulusan; (7) Standar Evaluasi; (8) Standar Pembiayaan. ${ }^{15}$

Dari kajian teori di atas peneliti dapat memberikan batasan bahwa layanan pendidikan agama adalah layanan administrasi, managerial, sosial dan transformasional yang diberikan sekolah dalam memfasilitasi siswa mendapatkan haknya tentang pendidikan agama (sesuai dengan agama yang dianutnya, yang meliputi aspek pengetahuan, sikap dan pengembangan karakter serta keterampilan keagamaan.

Religiusitas menurut Alport, G. W,. \& Ross, J. M., memiliki dua aspek orientasi yaitu intrinsik religious dan ektrinsic religious. Intrinsik menghidupkan agamanya dan ekstrinsik menggunakan agamanya. ${ }^{16}$ Menurut Donahue, M. J., religiusitas melihat setiap kejadian melalui kacamata agama, sehingga tercipta makna. ${ }^{17}$ Swanson dan Byrd (1998) religiusitas menekankan pada konsekwensi emosional dan sosial. ${ }^{18}$

Glock (1965) mengatakan bahwa religiusitas membuat manusia mengetahui, menghargai, memanfaatkan hidupnya dan berperilaku sesuai dengan ajaran agamanya. Agama menurutnya membuat manusia sadar akan makna hidup dan berbuat lebih baik untuk masa depan. Glock lebih jauh membuat 5 (lima) dimensi Religiusitas; (1) Religious Belief (The Ideological Dimension); (2)

${ }^{15}$ Peraturan Pemerintah Nomor 19 Tahun 2005.

${ }^{16}$ Allport. 1967. Personal Religius Orientation and Prejudice. New York: Journal Personality, hh. 447-457.

${ }^{17}$ Donahue. 1985. Intrinsic and extrinsic religiousness : Review and meta analysis. New York : Journal Personality, hh. 400-419.

${ }^{18}$ Byrd, was an African-American who was murdered by three white supremacists, in Jasper, Texas, on June 1998, hh.308-309. 
Religious Practice (The Ritual Dimension); (3) Religious Feeling (The Experintal Dimension); (4) Religious Knowledge (The Intelectual Dimension) dan (5) Religous Effect (The Consequential Dimension). ${ }^{19}$

Lebih jauh McDaniel (2009) mengatakan bahwa religiusitas sebagai kepercayaan kepada tuhan disertai dengan komitmen untuk mengikuti prinsip-prinsip yang diyakini dan ditetapkan tuhan. Religiusitas menurut Singh (2005) mempengaruhi sikap dan perilaku manusia. ${ }^{20}$

Quraish Sihab lebih lanjut mengatakan bahwa agama diperoleh manusia dari kemampuannya menggabungkan antara keindahan, kebaikan dan kebenaran. Keindahan dapat dilihat dari gemerlapnya bintang, kembang yang mekar, panorama yang eksotis, pemandangan yang menarik. Kebaikan dapat di temukan dengan angin yang segar dikala gerah, air yang sejuk dikala haus, panas yang nyaman di kala dingin. Kebenaran diperoleh dari proses sunnatullah yang terbentang di tengahtengah alam raya. Keindahan, kebaikan, dan kebenaran melahirkan kesucian. Manusia berusaha untuk mensucikan diri, sehingga ia berusaha menemukan yang maha suci, mengimplementasikan sifat-sifat kesucian dalam kehidupan. Religiusitas seseorang mendorongnya untuk berperilaku mulia di tengah-tengah kehidupan. ${ }^{21}$

Tingkat religiusitas bagian dari potensi kecerdasan religiusitas yang dimiliki oleh

${ }^{19}$ Glock. 1965. Religion and Society in Tension. Chicago, Rand Mcnally and Company, h. 312.

${ }^{20}$ Singh. 2005. Religiosity and Consumer Ethics, New York, Journal of Business, h. 175.

${ }^{21}$ Quraish Sihab. 2013. Membumikan Al-Qur'an Fungsi dan Peran Wahyu Dalam Kehidupan Masyarakat. Bandung, Mizan, hh. 325-326. manusia. Menurut Ancok Religiusitas berangkat dari adanya spiritualitas. Spiritualitas nilai yang inheren dalam diri individual, menjelma dalam bentuk sikap, personalitas, habituitas dan behavioralitas. ${ }^{22}$ Dari uraian di atas dapat di simpulkan bahwa religiusitas siswa adalah pengamalan ajaran agama yang dianut oleh siswa, teologi, ritual, dan etika dalam kehidupan sosial kemasyarakatan.

\section{Kerangka Teoritik}

Dari kajian literatur di atas terlihat bahwa layanan pendidikan agama tersebut secara esensial melakukan fungsi pelayanan dalam bentuk memberikan kepastian kepada siswa bahwa mereka di berikan pendidikan agama sesuai dengan agama masingmasing siswa. Pemberian pendidikan agama tersebut dengan mengembangkan isi materi pembelajaran agama dalam bentuk silabus, rencana pokok pembelajaran, bahan ajar dan lembar kegiatan siswa. Pendidikan Agama diajarkan oleh seorang guru agama yang telah tersertifikasi oleh pemerintah, dilakukan dengan proses pembelajaran yang telah terstandar.

Standar proses pembelajaran agama mencakup; guru memahami siswanya, menyampaikan materi pembelajaran dengan pengelolaan kelas yang interaktif, memulai dengan apersepsi, menyampaikan rencana pokok pembelajaran, menyampaikan pembelajaran dengan memastikan siswa menguasai materi tersebut. Pada akhirnya siswa memperoleh nilai akhir pendidikan agama.

${ }^{22}$ Djmaluddin Ancok, op., cit., h. 182. 
Layanan pendidikan agama di sekolah, ukuran yang diambil dengan mengembangkan indikator pemenuhan (1) standar pendidik; kepribadian, sosial, paedagogik dan keilmuan. (2) standar sarana dan prasarana; ruangan pembelajaran, perpustakaan, laboratorium, sumber belajar. (3) standar proses; interaktif, edukatif, imajinatif dan impropisasi. (4) standar penilaian; nilai harian, semester dan nilai akhir dan (5) standar kelulusan, siswa mencapai, melebihi dan melampaui Kualifikasi Kompetensi Minimal (KKM). Dari lima hal tersebut diukur secara kuantitatif, sehingga mendapat Nilai layanan pendidikan agama di sekolah. Nilai layanan pendidikan agama tersebut tentu diukur secara faktual pada sekolah yang menjadi sampling penelitian ini melalui Instrumen Pengumpulan Data (IPD).

Siswa yang bergabung pada sebuah unit layanan pendidikan atau satuan pendidikan tersebut, masing-masing individual siswa memiliki nilai religiusitas yang mutlak. religiusitas siswa adalah pengamalan ajaran agama yang dianut oleh siswa, teologi, ritual, dan etika dalam kehidupan sosial kemasyarakatan. Antar individu siswa dengan lainya memiliki variasi nilai. Permasalahannya apakah layanan pendidikan agama pada sekolah tersebut memiliki pengaruh (effect) terhadap religiusitas siswa.

Apakah sekolah yang memiliki layanan pendidikan agama tinggi mempengaruhi religiusitas siswanya. Apakah sekolah yang memiliki layanan pendidikan rendah mempengaruhi juga terhadap tingkat religiusitas siswanya.

\section{Hipotesis}

Dari kerangka teoritik di atas peneliti dapat mengemukakan hipotesis pertama, tidak terdapat pengaruh layanan pendidikan agama di sekolah terhadap religiusitas siswa. Kedua terdapat pengaruh layanan pendidikan agama di sekolah terhadap religiusitas siswa.

\section{METODOLOGI PENELITIAN}

Penelitian dilaksanakan di Kota Medan Sumatera Utara pada tahun ajaran 2015/2016. Metode yang digunakan adalah metode Expost Facto dengan desain Analisis kovarian 1X2. Sampel berjumlah 22 sekolah yang diambil dengan teknik purposive random sampling dari sekolah tingkat lanjutan atas SMA/SMK negeri dan swasta. Pengumpulan data awal survey tingkat layanan pendidikan agama dengan sampel kepala sekolah dan data religiusitas siswa dengan sampel beberapa siswa di sekolah. Analisis data dilakukan dengan tahapan berikut; (1) analisis deskriptif, yang meliputi perhitungan mean, median, modus, standar deviasi dan variansi; (2) uji persyaratan yang meliputi uji normalitas, uji homogenitas, uji linieritas, uji keberartian regresi dan uji kesejajaran regresi dan (3) uji hipotesis dengan menggunakan analisis kovarian.

\section{HASIL DAN PEMBAHASAN}

\section{Deskripsi data}

Data hasil penelitian yang dideskripsikan dalam bentuk analisis deskriptif yang meliputi mean, median, modus, standar deviasi dan variansi, kemudian dibuat dalam bentuk distribusi frekuensi dan histogram. 
Tabel 1

Deskripsi Data

\begin{tabular}{|c|c|c|c|}
\hline & & Religiusitas Siswa & Indek Layanan PA \\
\hline \multirow[t]{2}{*}{$\mathrm{N}$} & Valid & 22 & 22 \\
\hline & Missing & 0 & 0 \\
\hline \multicolumn{2}{|c|}{ Mean } & 47,95 & 1,50 \\
\hline \multicolumn{2}{|c|}{ Median } & 48,00 & 1,50 \\
\hline \multicolumn{2}{|c|}{ Mode } & 48 & $1^{\mathrm{a}}$ \\
\hline \multicolumn{2}{|c|}{ Std. Deviation } & 2,870 & ,512 \\
\hline \multicolumn{2}{|c|}{ Variance } & 8,236 & ,262 \\
\hline \multicolumn{2}{|c|}{ Range } & 11 & 1 \\
\hline \multicolumn{2}{|c|}{ Minimum } & 42 & 1 \\
\hline \multicolumn{2}{|c|}{ Maximum } & 53 & 2 \\
\hline \multicolumn{2}{|c|}{ Sum } & 1055 & 33 \\
\hline
\end{tabular}

Multiple modes exist. The smallest value is shown

Data SPSS For Window

Tabel 2

Distribusi Frekuensi Religiusitas Siswa

\begin{tabular}{|c|c|c|c|c|c|}
\hline & & Frequency & Percent & Valid Percent & Cumulative Percent \\
\hline \multirow[t]{12}{*}{ Valid } & 42 & 1 & 4,5 & 4,5 & 4,5 \\
\hline & 43 & 1 & 4,5 & 4,5 & 9,1 \\
\hline & 44 & 1 & 4,5 & 4,5 & 13,6 \\
\hline & 46 & 3 & 13,6 & 13,6 & 27,3 \\
\hline & 47 & 3 & 13,6 & 13,6 & 40,9 \\
\hline & 48 & 5 & 22,7 & 22,7 & 63,6 \\
\hline & 49 & 2 & 9,1 & 9,1 & 72,7 \\
\hline & 50 & 1 & 4,5 & 4,5 & 77,3 \\
\hline & 51 & 2 & 9,1 & 9,1 & 86,4 \\
\hline & 52 & 2 & 9,1 & 9,1 & 95,5 \\
\hline & 53 & 1 & 4,5 & 4,5 & 100,0 \\
\hline & Total & 22 & 100,0 & 100,0 & \\
\hline
\end{tabular}

Data SPSS For Window

Tabel 3

Distribusi Frekuensi Layanan Pendidikan Agama di Sekolah

\begin{tabular}{ccccc}
\hline & Frequency & Percent & Valid Percent & Cumulative Percent \\
\hline Valid 1 & 11 & 50,0 & 50,0 & 50,0 \\
2 & 11 & 50,0 & 50,0 & 100,0 \\
Total & 22 & 100,0 & 100,0 & \\
\hline
\end{tabular}

Sebelum dilakukan pengujian inferensial, terlebih dahulu dilakukan pengujian persyaratan analisis data yang meliputi: uji normalitas, uji homogenitas, uji linieritas, uji keberartian regresi dan uji kesejajaran regresi semuanya telah teruji dan memenuhi persyaratan untuk dilakukan uji hipotesis.
Tabel 4

Hasil Uji Normalitas Data

\begin{tabular}{|c|c|c|c|c|c|c|c|}
\hline & \multirow{2}{*}{$\begin{array}{c}\text { Indek } \\
\text { Layanan PA }\end{array}$} & \multicolumn{3}{|c|}{ Kolmogorov-Smirnov } & \multicolumn{3}{|c|}{ Shapiro-Wilk } \\
\hline & & Statistic & Df & Sig. & Statistic & $\mathrm{df}$ & Sig. \\
\hline \multirow[t]{2}{*}{ Religiusitas Siswa } & 1 & 160 & 11 & $200^{*}$ & ,937 & 11 & 480 \\
\hline & 2 & 193 & 11 & $200^{*}$ & 944 & 11 & 570 \\
\hline
\end{tabular}

Dari tabel 4 hasil uji normalitas data di atas di peroleh signifikansi 0,200 lebih besar dari 0,05, dengan demikian bahwa distribusi data adalah normal.

Tabel 5

Hasil Uji Homogenitas Data

\begin{tabular}{cccc}
\hline Levene Statistic & $\mathrm{df1}$ & $\mathrm{df2}$ & Sig. \\
\hline, 902 & 1 & 20 &, 354 \\
\hline
\end{tabular}

Dari tabel 5 hasil uji homogenitas data di atas di peroleh signifikansi 0,354 lebih besar dari 0,05, dengan demikian bahwa varian dari dua kelompok data adalah homogen.

Tabel 6

Hasil Uji Linieritas Data

\begin{tabular}{|c|c|c|c|c|c|c|}
\hline & & $\begin{array}{l}\text { Sum of } \\
\text { Squares }\end{array}$ & $\mathrm{df}$ & $\begin{array}{l}\text { Mean } \\
\text { Square }\end{array}$ & $\mathrm{F}$ & Sig. \\
\hline \multirow{3}{*}{$\begin{array}{l}\text { Religiusitas } \\
\text { Siswa * Indek } \\
\text { Layanan PA }\end{array}$} & $\begin{array}{l}\text { Between (Combined) } \\
\text { Groups }\end{array}$ & 5,500 & 1 & 5,500 &, 657 & ,427 \\
\hline & Within Groups & 167,455 & 20 & 8,373 & & \\
\hline & Total & 172,955 & 21 & & & \\
\hline
\end{tabular}

a. With fewer than three groups, linearity measures for Religiusitas Siswa * Indek Layanan PA cannot be computed.

Dari tabel 6 hasil uji linieritas data di atas di peroleh signifikansi 0,427 lebih besar dari 0,05, dengan demikian bahwa terdapat hubungan yang linier dari dua kelompok data.

\section{Analisis Hasil Penelitian}

Pengujian hipotesis penelitian yang diajukan dalam penelitian ini dilakukan analisis inferensial dengan program SPSS 
17.0. Model analisis yang digunakan adalah analis varian (ANAVA) dengan menggunakan prosedure GLM univariate dengan tujuan untuk menguji pengaruh faktor (factor effect) terhadap religiusitas siswa. Hasil pengujian pengaruh disajikan dalam tabel berikut:

Tabel 7

Ringkasan hasil uji Anava Pengaruh Layanan Pendidikan Agama di Sekolah terhadap Religiusitas Siswa.

\begin{tabular}{lccccccccc}
\hline Source & $\begin{array}{c}\text { Type III Sum } \\
\text { of Squares }\end{array}$ & df & $\begin{array}{c}\text { Mean } \\
\text { Square }\end{array}$ & F & Sig. $\begin{array}{c}\text { Partial Eta } \\
\text { Squared }\end{array}$ & $\begin{array}{c}\text { Noncent. } \\
\text { Para- } \\
\text { meter }\end{array}$ & $\begin{array}{c}\text { Observed } \\
\text { Power }\end{array}$ \\
\hline $\begin{array}{l}\text { Corrected } \\
\text { Model }\end{array}$ & $5,500^{\mathrm{a}}$ & 1 & 5,500 &, 657 &, 427 &, 032 &, 657 &, 121 \\
Intercept & 50592,045 & 1 & 50592,045 & 6042,481 &, 000 &, 997 & 6042,481 & 1,000 \\
ILP & 5,500 & 1 & 5,500 &, 657 &, 427 &, 032 &, 657 &, 121 \\
Error & 167,455 & 20 & 8,373 & & & & & \\
Total & 50765,000 & 22 & & & & & & \\
Corrected & 172,955 & 21 & & & & & & \\
Total & & & & & & & & & \\
\hline
\end{tabular}

a. R Squared $=, 032$ (Adjusted R Squared $=-, 017$ ) b. Computed using alpha $=, 05$

Hasil perhitungan uji Anava Dua Arah yang dilakukan dengan bantuan program SPSS 22 for Windows dapat dirangkum dalam tabel berikut :

Harga $F_{\text {tabel }}$ diperoleh sebagai berikut $\mathrm{F}_{(0,05)(20)}=2,464$. Sedangkan untuk $\alpha=$ 0,01 diperoleh harga $\mathrm{F}_{(0,01)(20)}=2,938$. Dari ringkasan uji pada Tabel VII kolom sumber variasi (source) pada baris Indek Layanan Pendidikan (ILP) memberikan hasil bahwa $\mathrm{F}_{\text {hitung }}=0,66<\mathrm{F}_{(0,05)(20)}=2,464$. Hasil uji menunjukkan $\mathrm{F}_{\text {hitung }}$ lebih kecil dari $\mathrm{F}_{\text {tabel }}$ berarti terima $\mathrm{H}_{0}$ pada $\alpha=0,05$. Dengan hasil uji hipotesis di atas, ini berarti tidak terdapat pengaruh layanan pendidikan agama di sekolah terhadap religiusitas siswa.

\section{Interpretasi/Pembahasan Dengan Mengacu Kepada Teori}

Dari hasil penelitian di atas telah nyata dan terbukti secara empirik bahwa religiusitas siswa antara sekolah yang memiliki layanan pendidikan agama tinggi dengan sekolah yang memiliki layanan pendidikan agama rendah tidak terdapat perbedaan yang signifikan. Religiusitas siswa lebih dominan bersifat personal, bukan diintervensi oleh layanan pendidikan agama di sekolah. Agus (2000) : Agama Dalam Kehidupan Manusia mengatakan bahwa exspresi religius ditemukan dalam budaya material, perilaku manusia, nilai, moral, hukum dan sebagainya.

Expresi keagamaan siswa dalam bentuk nilai, moral, perilaku dominan dipengaruhi oleh kehidupan keberagamaan keluarga, latar belakang sosial budaya, lingkungan sosial budaya yang ditempati siswa. Intervensi sekolah dalam keberagamaan siswa bukan hanya pada layanan pendidikan agama yang di sampaikan oleh guru agama siswa, tetapi sistem sosial budaya sekolah yang telah berakar.

Sistem sosial budaya sekolah yang telah berakar tersebut, menjadi atmosfir kehidupan sosial di sekolah. Suasanan kehidupan sosial di sekolah tercipta dari pengaruh setiap individu yang tengah berada dalam lingkungan sekolah tersebut, guru, tenaga kependidikan, orang tua siswa dan antar siswa di sekolah.

Sekolah sebagai lingkungan sosial dapat seperti digambar oleh Wayne (2013), berproses dari (1) Input; tekanan lingkungan, sumber daya manusia, sumber daya modal, materi, metode dan perlengkapan. (2) Proses transformasi; belajar, mengajar, sistem kultural, sistem politik, sistem individual (kognisi dan motivasi). (3) Output; prestasi, kepuasan kerja, kualitas menyeluruh. Keberagamaan siswa bukan hanya output 
dari hasil proses pembelajaran pendidikan agama, tetapi dari proses komprehensif yang ada di sekolah. Sekolah yang telah menciptkan sistem sosial, budaya dan politik, melahirkan atmosfier kehidupan terhadap sejumlah individu yang tergabung di dalamnya. ${ }^{23}$ Religiusitas bagian integreted dari atmosfer kehidupan tersebut. Sehingga religiusitas individual siswa tidak hanya karena pengaruh layanan pendidikan agama yang disampaikan di sekolah, tetapi seluruh gerakan komponen sistem yang ada di sekolah.

Seperti yang dikutip pada kajian literatur Glock (1965) Religion and Society in Tension mengatakan bahwa religiusitas membuat manusia mengetahui, menghargai, memanfaatkan hidupnya dan berperilaku sesuai dengan ajaran agamanya. ${ }^{24}$ Perilaku siswa sesuai dengan ajaran agamanya datang dari kesadaran spiritual individual yang dipengaruhi oleh doktrin kegamaan yang diperoleh siswa pada umumnya melalui ustad, pendeta, dan tokoh agama yang ia percai (personal trust), orang tua atau keluarga yang telah membiasakan mengamalkan agama dan di rumah ibadah (masjid, gereja, viara, kelenteng dan rumah ibadah lainnya). Agama lebih lanjut menurutnya membuat manusia sadar akan makna hidup dan berbuat lebih baik untuk masa depan.

Agama memberikan sumber inspirasi, motivasi kepada siswa untuk berbuat lebih baik untuk kehidupan dunia dan akhirat. Dalam Islam manusia disebut sebagai khalifah untuk mengatur, mengelola, dan menciptakan keseimbangan alam. Manusia

\footnotetext{
${ }^{23}$ Wayne, op. cit., h. 105

${ }^{24}$ Glock, loc. Cit.,
}

yang terbaik adalah manusia yang banyak mendatangkan manfaat terhadap alam, sebaliknya manusia yang jahat adalah manusia membuat kerusakan di alam.

Glock lebih jauh membuat 5 (lima) dimensi Religiusitas; (1) Religious Belief (The Ideological Dimension); (2) Religious Practice (The Ritual Dimension); (3) Religious Feeling (The Experintal Dimension); (4) Religious Knowledge (The Intelectual Dimension) dan (5) Religous Effect (The Consequential Dimension). Lima dimensi religiusitas yang dikembangkan oleh Glock tersebut secara umum menuntun, mengarahkan, dan memacu manusia untuk menciptakan tatanan yang terbaik di muka bumi ini. Ideologi pondasi utama bagi manusia untuk menjalani kehidupan. Ibadah memandu dan melatih manusia untuk berbuat yang terbaik dengan berusaha mendekatkan diri kepada sang pencipta dengan ritual-ritual khusus. Feeling mengasah jiwa untuk menjadi suci, bersih, murni dalam penghambaan kepada khalik, diwujudkan dalam tatanan sosial budaya dengan akhlaqul karimah. Knowledge membuat manusia cerdas untuk bekerja dan berbuat sesuatu yang terbaik dalam tata kelola kehidupan dunia yang berbasis nilai-nilai ketuhanan. Dan effect inti sari dalam pemahaman dan pengamalan keagamaan dalam kehidupan manusia yang membuahkan kehidupan yang terbaik (kesalehan sosial).

Kesalehan sosial diawali oleh kesalehan individual, keluarga dan sosial kemasyarakatan. Kehidupan sosial kemasyarakat yang baik akan menciptakan tatanan sosial yang regulatif, dinamis dan transformatif. Hal ini dapat terwujud dengan pengamalan religiusitas pada diri masing-masing individu yang hidup di 
tengah-tengah masyarakat. Individu yang tidak mengamalkan nilai-nilai religiusitas akan menjadi virus dalam kehidupan sosial masyarakat. Dengan demikian dapat dikatakan bahwa religiusitas sangat penting dalam kehidupan sosial kemasyarakatan.

Pembinaan religiusitas pada diri siswa bagian dari kewajiban sekolah, tetapi karena keterbatasan pembinaan sekolah, maka pembinaannya tidak hanya dibebankan kepada sekolah. Karena pembinaan religiusitas pada diri siswa tidak terikat oleh waktu dan tempat. Pembinaan religiusitas pada diri manusia sepanjang waktu dan dimana saja, maka variasi nilai religiusitas pada diri siswa tidak di dominasi pada pembinaan atau pelayanan pendidikan agama di sekolah tempat siswa, tetapi tergantung dari kerja individual siswa. Masing-masing siswa memiliki variasi nilai religiusitasnya, sesuai dengan latar belakang keluarga, pendidikan sebelumnya, tempat tinggal, intensitas keikut sertaan dalam kegiatan keagamaan pada komunitas tertentu.

Layanan pendidikan agama di sekolah, selain pembinaan kegamaan siswa, di tuntut juga untuk dapat memperhatikan siswa secara individual terkait dengan, latar belakang pembinaan agama di keluarga, aktivitas atau keikutsertaan dalam kegiatan keagamaan di komunitas sosial kegamaan, latar belakang pendidikan, latar belakang pendidikan sebelumnya dan aktifitas kegiatan keagamaan sebelumnya, serta kegiatan keagamaan siswa yang tengah berlangsung. Hal-hal inilah yang membuat varian nilai religiusitas diantara siswa di sekolah. Peningkatan kualitas dan kuantitas layanan pendidikan agama tentu terus di tingkatkan, karena layanan pendidikan agama berhubungan dengan pengetahuan keagamaan, sikap keagamaan dan perilaku keagamaan. Variabel ini masing-masing berhubungan dengan variabel religiusitas siswa. Tetapi tingkat layanan tinggi tidak secara otomatis membuat siswa memiliki nilai religiusitas tinggi, demikian juga sebaliknya tingkat layanan pendidikan agama rendah tidak otomatis membuat siswa memiliki nilai religiusitas rendah. Ada diantara beberapa sekolah yang memiliki layanan pendidikan tinggi, tetapi siswanya ada yang memiliki nilai religiusitas rendah, karena dipengaruhi oleh variabel lain, keluarga, masyarakat, kegiatan individu, aktifitas dalam komunitas kegamaan tertentu, bacaan, tontonan, dan lain-lain. Demikian juga sebaliknya ada sekolah yang memiliki layanan pendidikan rendah, tetapi banyak siswanya yang memiliki nilai religiusitas tinggi, karena juga dipengaruhi oleh variabel lain, keluarga, masyarakat, kegiatan individu, aktifitas dalam komunitas kegamaan tertentu, bacaan, tontonan, dan lain-lain.

\section{PENUTUP}

Dari hasil penelitian dan pembahasan di atas dapat peneliti simpulkan bahwa tidak terdapat perbedaan nilai religiusitas siswa dari sekolah yang memiliki layanan pendidikan tinggi dengan sekolah yang memiliki layanan pendidikan rendah. Layanan pendidikan tidak berpengaruh terhadap tingkat nilai religiusitas siswa.

Dari kesimpulan diatas dapat di sarankan bahwa pertama, sekolah jangan berpuas diri dengan hanya meningkatkan layanan pendidikan agama, karena layanan pendidikan agama tidak secara otomatis 
akan mempengaruhi tingkat nilai religiusitas siswa. Nilai religiusitas siswa di pengaruhi oleh berbagai variabel, diantaranya adalah latar belakang pendidikan sebelumnya, tingkat keberagaman di lingkungan keluarga, tingkat keberagamaan di lingkungan tempat siswa berada, tingkat keberagamaan di sekolah sebagai sebuah komunitas sosial dan keikutsertaan atau intensitas keagamaan yang dilakukan siswa pada komunitas tertentu.

Kedua, sekolah di samping melakukan layanan pendidikan agama secara formal, juga diperlukan melakukan layanan informal, non formal maupun individual. Sekolah memiliki data tentang masingmasing siswa, terkait dengan latar belakang religiusitasnya, tingkat religiusitas keluarga, religiusitas di lingkungan tempat siswa tinggal, aktifitasnya dalam komunitas kegamaan tertentu di masyarakat serta aktifitas siswa dalam pembinaan religiusitas di sekolah.

Ketiga, religiusitas sangat personal pada diri masing-masing siswa, guru agama dituntut tidak hanya memberikan pembelajaran agama secara keilmuan, tetapi harus mampu membangun atmosfer keberagamaan dalam kehidupan sosial di lingkungan sekolah. Lingkungan sekolah merupakan sistem sosial dalam pelapisan sosial budaya, ini mempengaruhi nilai religiusitas siswa. Guru agama menjadi aktor intelektual dalam menciptakan kehidupan religiusitas di tengah kehidupan sosial di sekolah, dengan melakukan koordinasi dan bersinergi dengan pimpinan dan komponen yang ada di lingkungan sekolah.

\section{UCAPAN TERIMAKASIH}

Penelitian ini dapat terealisasi dengan baik karena mendapat dukungan dari banyak pihak. Oleh karena itu, kami ucapkan terima kasih atas kerja sama dan dukungannya, terutama kepada Bapak kepala Puslitbang Pendidikan Agama dan Keagamaan yang telah menugaskan kami untuk meneliti ke Medan dalam rangka penelitian Layanan Pendidikan Agama di Beberapa Kota di Indonesia, dalam rangka mendapatkan indek layanan Pendidikan Agama. Kami sampaikan terima kasih kepada Bapak Kepala Kementerian Agama Kota Medan yang telah memberikan bantuan untuk pengumpulan data. Kepala Sekolah SMA/ SMK Negeri dan Swasta di Kota Medan yang telah membuka pintu kepada kami mendapatkan data. Teman-teman petugas lapangan yang telah membantu kerja sukarela membantu mengumpulkan data. Kami hanya mendoakan kepada Allah SWT semoga kerja keras, kerja cerdas dan kerja ikhlas dari semua pihak ini mendapatkan pahala dari-Nya, dijadikan amal saleh dalam pengembangan ilmu pengetahuan, membangun peradaban ke depan.

\section{DAFTAR PUSTAKA}

Agus (2000): Agama Dalam Kehidupan Manusia. Jakarta; UIN, h. 27.

Allport (1967): Personal Religius Orientation and Prejudice. New York, Journal Personality, h. 447-457.

Donahue (1985): Intrinsic and extrinsic religiousness : Review and meta analysis. New York, Journal Personality, h. 400419. 
Engkoswara (2001): Paradigma Manajemen Pendidikan Menyongsong Otonomi Daerah. Bandung, Yayasan Amal Keluarga, h. 50.

Glock (1965): Religion and Society in Tension. Chicago, Rand Mcnally and Company, h. 312.

Peraturan Pemerintah Nomor : 55 Tahun 2007. Jakarta, Mensesneg RI.

Robbin (2007): Organizational Behaviour. New York, Rinehalt, h.294.

Sihab, Quraish (2013): Membumikan AlQur'an Fungsi dan Peran Wahyu Dalam Kehidupan Masyarakat. Bandung, Mizan, h. 325-326.

Singh (2005): Religiosity and Consumer Ethics. New York, Journal of Business, h. 175.

Swanson (1998): Death Anxietyin Young Adualts as a Function of Religious Orientastion. New York, Death Studies, hh. 257-268.
Uhar Suharsaputra (2010): Administrasi Pendidikan. Bandung, Refika, h. 61.

Undang-Undang Sistem Pendidikan Nasional Nomor : 20 Tahun 2003. Jakarta. Menkumdangham.

Wayne (2014): Administrasi Pendidikan Teori, Riset, dan Praktik. Yogyakarta. Pustaka Pelajar, h. 48.

Jason A.Colquitt, Jeffery A.Lepine, Michael J. Wesson (2011): Organizational Behavior, Improving Performance and Commitment in the Workplace (Second Edition), New York, McGraw-Hill, h. 296.

Endang Saifuddin. (2004): Wawasan Islam (Pokok-Pokok Tentang. Paradigma dan Sistem ... Bandung: PT. Kiblat Buku. Utama. 